\title{
Pemerolehan Bahasa Pada Anak Berkebutuhan Khusus Di SLB Martapura OKU Timur
}

\author{
Sugiarti ${ }^{1}$, Herni Fitriani ${ }^{2}$ \\ STKIP Nurul Huda OKU Timur \\ E-mail: 1giarti@stkipnurulhuda.ac.id,2herni@stkipnurulhuda.ac.id
}

\begin{abstract}
Language acquisition or language acquisition is a process that takes place in the brain of a child when he gets his first language or mother tongue which means acquisition of language regarding his first language. Normal human brain functions and speech tools can certainly speak well. Similarly, mentally disabled children also need language to communicate or to voice their hearts to others. However, the intellectual capacity of mentally retarded children who are below the average makes them difficult to obtain language and they often experience interference in language. Language is very important for everyone to master. With language, humans can convey their thoughts and feelings to others and can capture and understand the symbols of others. Language acquisition is closely related to children's cognitive development, therefore language skills (linguistic abilities) will be in accordance with their cognitive abilities, because linguistic abilities are one of the main factors that can influence a child's success in mastering language. But as is well known that autistic children have cognitive barriers that also cause language development is also hampered. These obstacles can be seen from the imbalance of language development with the age of the calendar (cronolicalage). Nevertheless they also have the same rights as normal children to obtain language as a tool to communicate with their environment.
\end{abstract}

Keywords: Language Acquisition, Children with Special Needs, Special School

\section{Pendahuluan}

Bahasa merupakan sarana untuk berinteraksi dalam kehidupan seharihari di masyarakat. Baik interaksi antar individu, individu dengan kelompok, maupun interaksi antara kelompok dengan kelompok. Semua orang membutuhkan bahasa untuk berinteraksi dan berkomunikasi dengan orang lain. Proses interaksi tersebut dapat terjadi apabila satu sama lain saling

Pemerolehan Bahasa Pada Anak Berkebutuhan Khusus Di SLB Martapura 
mengerti dan saling memahami makna serta maksud dan tujuan yang ingin dicapai. Untuk itu, diperlukan alat komunikasi yang disebut bahasa. Bahasa sangat penting untuk dikuasai oleh setiap orang. Dengan bahasa, manusia dapat menyampaikan pikiran dan perasaannya kepada orang lain serta dapat menangkap dan memahami simbol- simbol dari orang lain.

Pemerolehan bahasa atau akuisisi bahasa adalah proses yang berlangsung di dalam otak seseorang kanak-kanak ketika dia memperoleh bahasa pertamanya atau bahasa ibunya yang berarti pemerolehan bahasa berkenaan dengan bahasa pertamanya. Manusia yang normal fungsi otak dan alat bicaranya tentu dapat berbahasa dengan baik. Begitu pula anak tunagrahita mereka juga membutuhkan bahasa untuk berkomunikasi atau untuk menyuarakan isi hatinya kepada orang lain. Namun, kapasitas kecerdasan anak tunagrahita yang berada di bawah rata-rata membuat mereka kesulitan untuk memperoleh bahasa dan mereka sering kali mengalami gangguan dalam berbahasa.

Menurut Troike Saville Muriel Pemerolehan bahasa erat kaitannya dengan perkembangan kognitif anak, oleh karena itu kemampuan berbahasa (kemampuan linguistik) akan sesuai dengan kemampuan kognitifnya, karena kemampuan linguistik merupakan salah satu faktor utama yang dapat memengaruhi kesuksesan seorang anak dalam menguasai bahasa. ${ }^{1}$ Namun seperti yang telah diketahui bahwa anak autistik memiliki hambatan dalam kognitif yang juga menyebabkan terhambat pula perkembangan bahasanya. Hambatan tersebut dapat dilihat dari ketidakseimbangan perkembangan bahasa dengan usia kalendernya (cronolicalage). Meskipun demikian mereka juga memiliki hak yang sama layaknya anak normal untuk memperoleh bahasa sebagai alat untuk berkomunikasi dengan lingkunganya.

${ }^{1}$ Troike Saville Muriel., Introducing Second Language Acquistion, (Cambridge: Cambridge, 2006)

Pemerolehan Bahasa Pada Anak Berkebutuhan Khusus Di SLB Martapura 
Bahasa merupakan alat komunikasi yang terorganisasi dalam bentuk satuan-satuan, seperti kata, kelompok kata, klausa, dan kalimat yang diungkapkan baik secara lisan maupun tulis. Terdapat banyak sekali definisi bahasa, dan definisi tersebut hanya merupakan salah satu di antaranya. Anda dapat membandingkan definisi tersebut dengan definisi sebagai berikut: bahasa adalah sistem komunikasi manusia yang dinyatakan melalui susunan suara atau ungkapan tulis yang terstruktur untuk membentuk satuan yang lebih besar, seperti morfem, kata, dan kalimat, yang diterjemahkan dari bahasa Inggris: "the system of human communication by means of a structured arrangement of sounds (or written representation) to form lager units, eg. morphemes, words, sentences". ${ }^{2}$

Menurut Pamuji Bahasa seseorang mencerminkan pikirannya, semakin terampil seseorang berbahasa semakin jelas dan cerah jalan pikirannya. Keterampilan tersebut hanya bisa diperoleh dari praktek dan latihan. ${ }^{3}$ Yosfan Azwandi mengatakan bahwa Penguasaan bahasa baik bahasa ekspresif maupun bahasa reseptif penting bagi anak autis agar dapat berkomunikasi, berinteraksi, menyampaikan ide/pikirannya, dan menyesuaikan dengan lingkungannya. Dengan mempunyai kemampuan berbahasa yang baik, anak autis dapat mengikuti pembelajaran di kelas dengan baik pula. Namun, karena anak autis mengalami gangguan dalam hal berbahasa dan berkomunikasi maka anak autis pun mengalami kesukaran dalam memahami arti kata-kata serta penggunaan bahasa yang sesuai konteksnya. ${ }^{4}$

${ }^{2}$ Richards, J., Platt, J. \& Weber, H. 1985. Longman Dictionary of Applied Linguistics. Harlow: Longman, 1985: 153.

3Pamuji, Model Terapi Terpadu Bagi Anak Autisme, (Jakarta: Departemen Pendidikan Nasional,2007)

${ }^{4}$ Yosfan Azwandi., Mengenal dan Membantu Penyandang Autisme, (Jakarta: Departemen Pendidikan Nasional,2005)

Pemerolehan Bahasa Pada Anak Berkebutuhan Khusus Di SLB Martapura 
Bahasa mengemban tiga fungsi utama, yaitu fungsi ideasional, fungsi interpersonal, dan fungsi tekstual. Ketiga fungsi ini disebut fungsi metafungsional, dan ketiga fungsi tersebut menunjukkan realitas yang berbeda. Di bawah fungsi ideasional, bahasa digunakan untuk mengungkapkan realitas fisik-biologis serta berkenaan dengan interpretasi dan representasi pengalaman. Di bawah fungsi interpersonal, bahasa digunakan untuk mengungkapkan realitas sosial dan berkenaan dengan interaksi antara penutur/penulis dan pendengar/pembaca. Di bawah fungsi tekstual, bahasa digunakan untuk mengungkapkan realitas semiotis atau realitas simbol dan berkenaan dengan cara penciptaan teks dalam konteks. ${ }^{5}$

\section{Metode}

Metode adalah suatu proses atau cara sistematis yang digunakan untuk mencapai tujuan tertentu dengan efisiensi, biasanya dalam urutan langkahlangkah tetap yang teratur. Kata metode (method) berasal dari bahasa Latin dan juga Yunani, methodus yang berasal dari kata meta yang berarti sesudah atau di atas, dan kata hodos, yang berarti suatu jalan atau suatu cara. Metode secara harfiah menggambarkan jalan atau cara suatu totalitas yang akan dicapai atau dibangun.

Mendekati suatu bidang secara metodis berarti memahami atau memenuhinya sesuai dengan rencana, mengatur berbagai kepingan atau tahapan secara logis dan menghasilkan sebanyak mungkin hubungan. Metode dan sistem membentuk hakikat ilmu. Sistem bersangkutan dengan isi ilmu, sementara metode berkaitan dengan aspek formal. Lebih tepat, sistem berarti keseluruhan pengetahuan yang teratur atau totalitas isi dari ilmu.

${ }^{5}$ Martin, J. R. (1992). English Text: System and Structure. Philadelphia/ Amsterdam: John Benjamins Publishing Company 1992: 6. 
Metode yang digunakan dalam pelaksanaan kegiatan ini adalah ceramah. Metode ceramah digunakan dalam menyampaikan materi-materi yang berguna dalam pemberdayaan ini. Adapun materi yang disampaikan meliputi :
a. Tanggal Pelaksanan
: 07 Oktober 2019
b. Tempat Pelaksanaan
: Sekolah SLB Martapura OKU Timur
c. Waktu Pelaksanaan
: Pukul 08.00-13.30

\section{Tabel 1. Pemerolehan Bahasa Pada Anak Berkebutuhan Khusus di Sekolah SLB Martapura OKU Timur}

\begin{tabular}{|c|c|c|}
\hline Materi Pelatihan & Narasumber & Keterangan \\
\hline Pembukaan & $\begin{array}{l}\text { Suhartono, M.Pd.I. Wakil } \\
\text { Ketua I STKIP Nurul } \\
\text { Huda }\end{array}$ & Pkl. 08.00-08.30 \\
\hline Sambutan & $\begin{array}{l}\text { Wakiren } \\
\text { Kepala Sekolah SLB }\end{array}$ & Pkl. 08.30-09.00 \\
\hline $\begin{array}{l}\text { Cara membantu } \quad \text { anak } \\
\text { berkebutuhan khusus }\end{array}$ & $\begin{array}{l}\text { Sugiarti, M.Pd., dan } \\
\text { Herni Fitriani, M.Pd. }\end{array}$ & Pkl. 09.00-10-00 \\
\hline $\begin{array}{l}\text { Proses pembelajaran dan } \\
\text { kurikulum yang terdapat pada } \\
\text { sekolah dari hasil kunjungan } \\
\text { observasi }\end{array}$ & Sugiarti, M.Pd. & Pkl . 10-00-11.00 \\
\hline $\begin{array}{l}\text { Kurikulum yang terdapat pada } \\
\text { sekolah dari hasil kunjungan } \\
\text { observasi }\end{array}$ & $\begin{array}{l}\text { Sugiarti, M.Pd., dan } \\
\text { Herni Fitriani, M.Pd. }\end{array}$ & Pkl. 11.00-12.30 \\
\hline Isoma & - & Pkl. $12.30-13.00$ \\
\hline Penutupan & Tim & Pkl.13.00 - 13.30 \\
\hline
\end{tabular}

Sumber: Dokumentasi, 2019 
Metode yang tepat dalam kegiatan ini sebagai langkah strategi dalam menghimpun informasi tentang atmosfir di sekolah luar biasa tersebut, baik dari sitem pengajar, tenaga pengajar, dan siswa yang di ajar. Dengan komunikasi yang tepat dalam menggali data dengan pendekatan persuasif terhadap responden, maka para pengabdi akan tahu tentang apa yang kurang dan yang perlu mendapatkan tambahan pembenahan terhadap keadaan dan metode yang ada di sekolah tersebut.

Memang tidak mudah dalam memberikan penanganan yang tepat untuk anak berkebutuhan khusus. Jenis anak berkebutuhan khusus sesuai dengan Kementerian Pemberdayaan Perempuan dan Perlindungan Anak Republik Indonesia Tahun 2013 sebagai berikut:

1) Anak disabilitas penglihatan adalah anak yang mengalami gangguan daya penglihatan berupa kebutaan menyeluruh (total) atau sebagian (low vision).

2) Anak disabilitas pendengaran adalah anak yang mengalami gangguan pendengaran, baik sebagian ataupun menyeluruh, dan biasanya memiliki hambatan dalam berbahasa dan berbicara.

3) Anak disabilitas intelektual adalah anak yang memiliki inteligensia yang signifikan berada dibawah rata-rata anak seusianya dan disertai dengan ketidakmampuan dalam adaptasi perilaku, yang muncul dalam masa perkembangan.

4) Anak disabilitas fisik adalah anak yang mengalami gangguan gerak akibat kelumpuhan, tidak lengkap anggota badan, kelainan bentuk dan fungsi tubuh atau anggota gerak.

5) Anak disabilitas sosial adalah anak yang memiliki masalah atau hambatan dalam mengendalikan emosi dan kontrol sosial, serta berperilaku menyimpang. 
6) Anak dengan gangguan pemusatan perhatian dan hiperaktivitas (GPPH) atau attention deficit and hyperactivity disorder (ADHD) adalah anak yang mengalami gangguan perkembangan, yang ditandai dengan sekumpulan masalah berupa ganggguan pengendalian diri, masalah rentang atensi atau perhatian, hiperaktivitas dan impulsivitas, yang menyebabkan kesulitan berperilaku, berfikir, dan mengendalikan emosi.

7) Anak dengan gangguan spektrum autisma atau autism spectrum disorders (ASD) adalah anak yang mengalami gangguan dalam tiga area dengan tingkatan berbeda-beda, yaitu kemampuan komunikasi dan interaksi sosial, serta pola-pola perilaku yang repetitif dan stereotipi.

8) Anak dengan gangguan ganda adalah anak yang memiliki dua atau lebih gangguan sehingga diperlukan pendampingan, layanan, pendidikan khusus, dan alat bantu belajar yang khusus.

9) Anak lamban belajar atau slow learner adalah anak yang memiliki potensi intelektual sedikit dibawah rata-rata tetapi belum termasuk gangguan mental. Mereka butuh waktu lama dan berulang-ulang untuk dapat menyelesaikan tugas-tugas akademik maupun non akademik.

10) Anak dengan kesulitan belajar khusus atau specific learning disabilities adalah anak yang mengalami hambatan atau penyimpangan pada satu atau lebih proses psikologis dasar berupa ketidakmampuan mendengar, berpikir, berbicara, membaca, menulis, mengeja dan berhitung.

11) Anak dengan gangguan kemampuan komunikasi adalah anak yang mengalami penyimpangan dalam bidang perkembangan bahasa wicara, suara, irama, dan kelancaran dari usia rata-rata yang 
disebabkan oleh faktor fisik, psikologis dan lingkungan, baik reseptif maupun ekspresif.

12) Anak dengan potensi kecerdasan dan/atau bakat istimewa adalah anak yang memiliki skor inteligensi yang tinggi (gifted), atau mereka yang unggul dalam bidang-bidang khusus (talented) seperti musik, seni, olah raga, dan kepemimpinan. ${ }^{6}$

\section{Hasil dan Diskusi}

\section{Hasil}

Penanganan pada anak berkebutuhan khusus dibutuhkan orang-orang sekitar seperti orang tua ataupun keluarga yang mampu memberikan pelayanan kepada anak berkebutuhan khusus dan tanggung jawab mereka untuk memeberikan hak yang sama kepada anak berkebutuhan khusus dengan anak yang tidak yang berkebutuhan khusus. Disinilah pengetahuan orang tua untuk menangani anak berkebutuhan khusus diperlukan, Seperti :

1) Orangtua atau keluarga berkonsultasi kepada guru, dokter, atau psikiater.

2) Menempatkan anak pada sekolah yang sesuai dengan kebutuhan anak untuk mempermudah pemberian materi pembelajaran pada anak.

3) Orang tua atau keluarga tidak membedakan anak berkebutuhan khusus dengan anak normal.

4) Memberikan anak kesempatan untuk anak mengembangkan minatnya yang akan berujung pada penemuan potensi alami pada anak berkebutuhan khusus.

5) Membiarkan anak bersosialisasi dengan lingkungan sekitar.

${ }^{6}$ Kementerian Pemberdayaan Perempuan dan Perlindungan Anak Republik Indonesia Tahun 2013. Panduan Penanganan Anak Berkebutuhan Khusus Bagi Pendamping (Orang Tua, Keluarga, Dan Masyarakat), 2013: 8-9. 
Orang tua dan keluarga harus mengetahui perkembangan anak berkebutuhan khusus dengan rutin membawa anak ke dokter, atau psikiater untuk berkonsultasi. Anak merupakan amanah yang harus dijaga dan diperhatikan aktivitas dan kebutuhannya. Karena anak berkebutuhan khusus bukanlah penyakit nyang enular, namun memerlukan perhatian lebih dibandingkan dengan anak-anak yang lain.

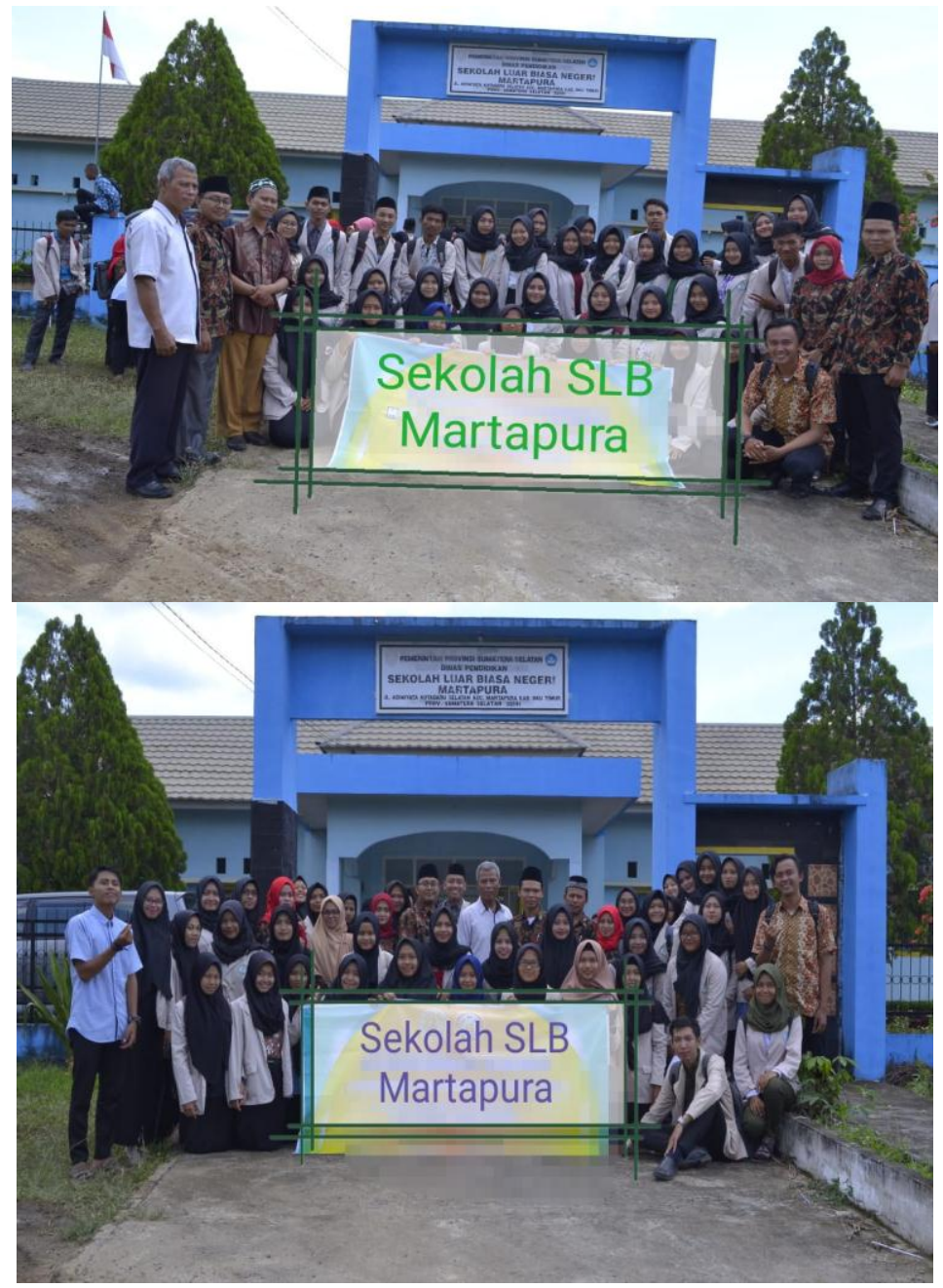

Gambar 1. Sekolah SLB Martapura (Sumber: Dokumentasi, 2019) 


\section{Diskusi}

Anak berkebutuhan khusus adalah anak yang mengalami keterbatasan atau keluarbiasaan, baik fisik, mental-intelektual, sosial, maupun emosional, yang berpengaruh secara signifikan dalam proses pertumbuhan atau perkembangannya dibandingkan dengan anak-anak lain yang seusia dengannya.

Perlu menjadi catatan bahwasannya anak yang berkebutuhan khusus sesuai dengan Kementerian Pemberdayaan Perempuan dan Perlindungan Anak Republik Indonesia Tahun 2013 sebagai berikut:

1) Anak berkebutuhan khusus adalah amanah Tuhan Yang Maha Kuasa yang harus dijaga, dirawat, dan dipenuhi haknya. Untuk itu, orangtua, keluarga, dan masyarakat perlu menerima keberadaan anak tersebut dengan ikhlas. Hindarkan dari perasaan cemas, kecewa, khawatir, marah, menyalahkan diri sendiri dan orang lain, serta putus asa yang berlarut larut.

2) Menelantarkan anak berkebutuhan khusus merupakan perilaku yang melanggar Hak Asasi Manusia. Untuk itu, orangtua, keluarga, dan masyarakat tidak diperbolehkan menyembunyikan atau menelantarkan anak tersebut

3) Anak berkebutuhan khusus mempunyai hak yang sama dengan anak lain dan dapat hidup mandiri, berprestasi sesuai dengan minat dan potensi yang dimiliki. Untuk itu, orangtua, keluarga, dan masyarakat wajib bertanggungjawab memenuhi hak-hak anak dalam segala aspek kehidupan, seperti bersosialisasi di lingkungan, berekreasi, dan berkegiatan lain yang bertujuan memperkenalkan anak berkebutuhan khusus dengan kehidupan di luar rumah. 
4) Anak berkebutuhan khusus bukan penyakit dan tidak menular. Oleh karena itu, orangtua, keluarga, dan masyarakat perlu menyebarluaskan informasi tentang hal dimaksud, termasuk informasi mengenai prestasi atau kesuksesan yang didapat oleh anak berkebutuhan khusus.

5) Orangtua, keluarga, dan masyarakat wajib memberikan pendampingan di bidang agama masing-masing, pendidikan, kesehatan dan kehidupan sosial.

6) Orangtua, keluarga, dan masyarakat perlu mempunyai keterampilan dalam merawat dan mengasuh anak yang berkebutuhan khusus melalui pelatihan-pelatihan.

7) Orangtua, keluarga perlu konsisten dan bersikap terbuka terhadap lingkungan sekitar dalam menangani anak berkebutuhan khusus.

8) Orangtua, keluarga harus mempunyai kemampuan teknis dan menstimulasi sedini mungkin perkembangan anak berkebutuhan khusus di rumah dan lingkungannya. ${ }^{7}$

Penanganan anak berkebutuhan khusus, memerlukan keberpihakan kultural dan struktural dari berbagai pihak baik orangtua, masyarakat dan pemerintah. Hal ini karena masih adanya pemahaman yang keliru dan sikap diskriminatif terhadap anak berkebutuhan khusus di lingkungan keluarga dan masyarakat, baik dalam bentuk verbal maupun non verbal. Selain itu anak berkebutuhan khusus rentan mendapatkan kekerasan dan perlakuan salah.

Dalam menangani anak-anak berkebutuhan khusus, para pendamping memerlukan pengetahuan tentang anak-anak tersebut, keterampilan mengasuh dan melayaninya. Anak berkebutuhan khusus perlu mendapat

${ }^{7}$ Kementerian Pemberdayaan Perempuan dan Perlindungan Anak Republik Indonesia Tahun 2013. Panduan Penanganan Anak Berkebutuhan Khusus Bagi Pendamping (Orang Tua, Keluarga, Dan Masyarakat), 2013: 10. 
dorongan, tuntunan, dan praktek langsung secara bertahap. Potensi yang dimiliki anak-anak berkebutuhan khusus akan tumbuh berkembang seiring dengan keberhasilan peran pendamping dalam memahami dan memupuk potensi anak-anak tersebut.

Masalah anak berkebutuhan khusus merupakan masalah yang cukup kompleks secara kuantitas maupun kualitas. Mengingat berbagai jenis anak berkebutuhan khusus mempunyai permasalahan yang berbeda-beda, maka dibutuhkan penanganan secara khusus. Jika anak berkebutuhan khusus mendapatkan pelayanan yang tepat, khususnya keterampilan hidup (life skill) sesuai minat dan potensinya, maka anak akan lebih mandiri. Namun, jika tidak ditangani secara tepat, maka perkembangan kemampuan anak mengalami hambatan dan menjadi beban orangtua, keluarga, masyarakat dan negara. Orangtua atau keluarga sebagai pemberi layanan utama terhadap anak berkebutuhan khusus, pada umumnya masih kurang mempunyai kesadaran dan tanggung jawab untuk memberikan persamaan hak dan kesempatan bagi anakanak tersebut. Hal ini dikarenakan kurangnya pengetahuan orangtua atau keluarga tentang bagaimana merawat, mendidik, mengasuh dan memenuhi kebutuhan anak-anak tersebut. Orangtua atau keluarga merupakan faktor terpenting dalam memfasilitasi tumbuh kembang dan perlindungan anak berkebutuhan khusus. ${ }^{8}$

\section{Simpulan}

Pemerolehan bahasa erat kaitannya dengan perkembangan kognitif anak, oleh karena itu kemampuan berbahasa (kemampuan linguistik) akan sesuai dengan kemampuan kognitifnya, karena kemampuan linguistik merupakan salah satu faktor utama yang dapat memengaruhi kesuksesan

${ }^{8}$ Kementerian Pemberdayaan Perempuan dan Perlindungan Anak Republik Indonesia Tahun 2013. Panduan Penanganan Anak Berkebutuhan Khusus Bagi Pendamping (Orang Tua, Keluarga, Dan Masyarakat), 2013: 22.

Pemerolehan Bahasa Pada Anak Berkebutuhan Khusus Di SLB Martapura 
seorang anak dalam menguasai bahasa. Namun seperti yang telah diketahui bahwa anak autistik memiliki hambatan dalam kognitif yang juga menyebabkan terhambat pula perkembangan bahasanya. Hambatan tersebut dapat dilihat dari ketidakseimbangan perkembangan bahasa dengan usia kalendernya (cronolicalage). Meskipun demikian mereka juga memiliki hak yang sama layaknya anak normal untuk memperoleh bahasa sebagai alat untuk berkomunikasi dengan lingkunganya.

\section{Daftar Referensi}

Apriyanto, Nunung. 2012. Seluk Beluk Tunagrahita dan Strategi Pembelajarannya. Yogyakarta: Javalitera.

Dardjowidjojo, Soenjono, 2005. Pengantar Pemahaman Bahasa Manusia. Jakarta: Yayasan Obor Indonesia.

Dardjowidjojo, Soenjono. 2010. Psikolingustik: Pengantar Pemahaman Bahasa Manusia. Jakarta: Yayasan Obor Indonesia.

Ellis, Rod.1996. The Study of Second language Acquisition. New York: Oxford University Press.

Handojo. 2008. Autisme: Petunjuk \& Praktis \& Pedoman Materi untuk Mengajar Anak Normal, Autis \& Prilaku Lain. Jakarta: Bhuana Ilmu Populer.

Kementerian Pemberdayaan Perempuan dan Perlindungan Anak Republik Indonesia Tahun 2013. Panduan Penanganan Anak Berkebutuhan Khusus Bagi Pendamping (Orang Tua, Keluarga, Dan Masyarakat). diakses di https://www.kemenpppa.go.id/lib/uploads/list/b3401panduan-penanganan-abk-bagi-pendamping-_orang-tua-keluarga-danmasyarakat.pdf.

Pamuji. 2007. Model Terapi Terpadu Bagi Anak Autisme. Jakarta: Departemen Pendidikan Nasional.

Richards, J., Platt, J. \& Weber, H. 1985. Longman Dictionary of Applied Linguistics. Harlow: Longman.

Sobur, Alex. 2006. Semiotika Komunikasi. Bandung: Rosdakarya.

Sukmawati, Fitri. 2010. Kecerdasan Majemuk pada Anak Autisme. Pontianak: STAIN Pontianak Press.

Suhardi. 2013. Pengantar Linguistik Umum. Jogjakarta: Ar-ruzz Media.

Sumarsono, 2011.Sosiolinguistik. Yogyakarta: Pustaka Pelajar.

Tarigan, Henry Guntur, 2009. Psikolinguistik. Bandung: Angkasa. 
Tarigan, Henry Guntur. 2015. Berbicara Sebagai suatu Ketrampilan Berbahasa. Bandung: Angkasa.

Troike, Saville, Muriel. 2006. Introducing Second Language Acquistion. Cambridge: Cambridge University Press.

Yosfan, Azwandi. 2005. Mengenal dan Membantu Penyandang Autisme. Jakarta: Departemen Pendidikan Nasional.

Zulela. 2012. Pembelajaran Bahasa Indonesia. Bandung: Remaja Rosdakarya. 